Interacting state and non-state actors in hybrid settings of public service delivery

WORKING PAPER

Accepted for publication in

Administration and Society, 2013

Author

Dr. Jeroen van der Heijden

Assistant Professor

Australian National University, Regulatory Institutions Network (RegNet)

University of Amsterdam, Amsterdam Law School

j.j.vanderheijden@anu.edu.au

www.jeroenvanderheijden.net

\begin{abstract}
Public services are increasingly delivered through hybrid settings of state and non-state actors. A key characteristic of such settings is the interaction between these actors. Different interactions may have different impacts on the outcomes of the particular settings. Yet to date, this key characteristic has received limited attention in scholarship. This article addresses this knowledge gap by presenting an exploratory comparative case study of two very similar hybrid settings that differ in the type of interaction between state and non-state actors.
\end{abstract}

Key words: collaborative governance, hybrid governance, privatization, public service delivery, regulatory enforcement 


\section{Interacting state and non-state actors in hybrid settings of public service delivery}

\section{Introduction}

Various institutional settings exist for the delivery of public services such as transport, communication, housing, healthcare, and education. This paper focuses on a specific institutional setting: one in which both state and non-state service providers provide services and service recipients may choose between these providers. Another way of framing this particular setting is to say that the public is provided with the freedom to choose a particular service provider. This hybrid setting is gaining prominence in the delivery of public services such as housing, education, and healthcare, and it has gained substantial attention in scholarly literature (Cellini, Pignataro, \& Rizzo, 2000; Davidson, 1999; Fotaki et al., 2005; Fotaki et al., 2008; Giddens, 2000; Greener \& Powell, 2008; Minow, 2011; Petersen, 2010; Rothstein, 1998).

When studying hybrid settings, scholars generally address the question of how nonstate sector service providers affect the outcomes of service delivery. Yet, hybrid settings have more characteristics than just the extent of non-state involvement. Another characteristic is the type of interaction between the public and private sector service providers. This key characteristic and its impact on the outcomes of a hybrid setting, however, is an insufficiently studied aspect of these hybrid settings of service delivery. This article addresses this key characteristic and aims to provide a more nuanced approach for studying such settings.

In this article, competitive and complementary interactions are considered to be the two basic forms of interaction between state and non-state service providers in a hybrid setting (cf. Trubek \& Trubek, 2007). Other, more nuanced, forms of interaction are likely to exist between state and non-state service providers in hybrid settings (e.g. Barnard, 1938; Jordan, Wurzel, \& Zito, 2005; and related, see Trubek \& Trubek, 2007) but, for the sake of the clarity of the argument that a focus on interactions matters in gaining a better understanding of hybrid forms of service delivery, no other relationships will be examined here.

A focus on these interactions in our studies of hybrid forms of service delivery may help us to better understand the circumstances in which hybridization produces desired outcomes, and the circumstances in which it does not. For instance, a competitive hybrid setting may be expected to impact on service provision in terms of time and costs; it may be expected to on the actual service providers in terms of increased levels of education, skills, and expertise of their personnel; and it may be expected to impact on the actual services provided in terms of meeting the needs of service recipients (e.g. Hodge, 2000). However, all this may very well come with undesired costs, which are most likely related to inequality and social segregation (cf. Rothstein, 1998). Different relationships between service providers may very well help to fine-tune the outcomes of hybrid settings. 
This then leaves us with the following relevant question: To what extent do different interactions between state and non-state service providers have a different impact on the outcome of hybrid settings? This article builds around this question.

The remainder of this paper is structured as follows. Section 2 of this article discusses the literature on hybrid settings of public service delivery and it specifically identifies the gap in our current understanding of such settings - that is, the impact of the type of interaction between state and non-state service deliverers on the hybrid setting. Then, to exemplify the relevance of including the interaction as a variable in our studies, an illustrative case study is presented. The study compares two cases of similar public service delivery in highly comparable contexts that are characterized by different types of interaction: a competitive interaction in one case (building control and related services in Australian jurisdictions), and a complementary interaction in the other case (building control and related services in Canadian jurisdictions). Section 3 discusses the research design, research methodology, and data analysis techniques. Section 4 discusses the illustrative case study; and finally, section 5 draws conclusions. It should be noted that the research design that is chosen does not aim to make empirical generalizations about the two types of interactions addressed in this article.

\section{Hybrid forms of public service delivery}

Various studies present rationales for hybrid settings of public service delivery (Daniels, 1990; Dowding, 2006; Le Grand, 2007; Noorderhaven, 1995). The first rationale corresponds with the classic neo-liberal arguments relating to the effectiveness and efficiency that are expected to result from privatizing, outsourcing, or contracting out service delivery to nonstate service providers (Harvey, 2005; Hodge, 2000; Osborne \& Gaebler, 1992). Yet, these arguments do not provide a solid rationale for a hybrid setting, which is characterized by a combination of non-state and state service providers. Keeping state service providers in the hybrid setting may thus be expected to have an advantage over fully outsourcing, contracting out, or privatizing service delivery. This is where the second rationale comes in. This second rationale relates to the legitimacy-efficiency trade-off that so often has to be made in public policy making (cf. Rothstein, 1998); that is that in choosing efficiency it is often found that legitimacy has to give way (much work on this trade-off can be traced back to Habermas, 1976). In a hybrid setting of public service delivery this may result in social segregation when (non-state) service providers only provide services when it is profitable to do so-creaming the market-whereas delivery of services to all in need is required (cf. Van Slyke, 2003). Including state service provision in service delivery may be a solution which ensures that services are accessible for all in need of these, instead of only those who can pay for services - state service providers then have a redistributive function (cf. Korpi \& Palme, 1988). Alternatively, resource-poor service recipients may be given (financial) support to obtain services from non-state service providers, for example school vouchers (Baggesen Klitgaard, 2008). 
Studies that address hybrid settings often question how service provision by nonstate service providers differs from that of state service providers, or how the range of nonstate service providers affects service delivery as a whole (for overviews, see Fotaki, et al., 2005; Fotaki, et al., 2008). These studies, for example, compare cross-nationally or crosssectorally how the inclusion of non-state service providers plays out in a setting that was formerly occupied by state service providers only (e.g. Davidson, 1999; Greener \& Powell, 2008; Ham \& Brommels, 1994). Such studies often describe the features of a sector or a country that are likely to be important in the successful implementation of non-state service provision: economies of scale; asset-specificities; heterogeneity, repetitiveness, and complexity of the service delivered; and, the level to which the service is mandatory to its users (Le Grand, 2007; Williamson, 1996).

Yet, hybrid settings are defined by more characteristics than just the extent of nonstate service provision. Another characteristic concerns the nature of the interaction between the state and non-state service providers. This key aspect of hybrid settings is however not taken up in the literature. Most studies of hybrid settings do not consider the interaction between service providers at all, and the few that do assume that this interaction is competitive (for excellent reviews of the literature, see Fotaki, et al., 2005; Fotaki, et al., 2008; and see Fotaki, 2011 for a study that addresses different interactions). We may criticize this literature for overlooking this second characteristic and question what (other) types of interaction exist. Furthermore, we may also question whether or not the interaction affects the hybrid setting.

If a hybrid setting is introduced to increase the effectiveness or efficiency of service delivery, we may assume that state and non-state service providers have to ensure that service recipients base their choice of a particular service provider on the quality, or the costs, of the services provided. In other words, both economic theory and organizational theory would predict that the state and non-state service providers have access to limited resources (the service recipients, or better, their money), and, in order to ensure the survival of their organization, they have to compete for these resources (Parkin, Powell, \& Matthews, 2005; Pugh, 2007). However, if the hybrid setting is introduced to overcome potential segregation between service recipients, we may assume that one type of service provider is introduced to provide those services that the other type of service provider is unable or unwilling to provide. This may, for instance, be because it is unprofitable for the latter to do so, or because the latter lacks the knowledge, means or expertise to do so. In such situations, the two types of service provider would exist side by side under a noncompetitive, or complementary interaction (terminology from, Young, 2006). This idea of a complementary form of service delivery fits within a broader idea of redistribution, as discussed in welfare state and social justice theorizing (Pierson \& Casteles, 2006).

As indicated earlier, current literature falls short in addressing the impact of the interaction between service providers on the outcomes of hybrid settings. The next sections address this gap in our understanding by presenting an illustrative case study, which contrasts a competitive hybrid setting with a non-competitive hybrid setting. 
Introducing the illustrative case study

To understand whether or not, or to what extent, different types of interaction affect the delivery of public services one would ideally compare two or more settings identical in every respect, except for the nature of the interaction between the state and non-state service providers. If the settings showed different outcomes in terms of public service delivery, the researcher could assume that there was an association between the difference in interaction (explanatory variable) and outcome in terms of service delivery (dependent variable). This classic research design dates back to John Stuart Mill's Method of Difference (Mill, 1851 [1843]), but is generally criticized for the fact that in social reality the researcher will be unable to find a number of settings that meet the strict criteria of similarity and difference. Further, the designs are subject to severe selection bias as the settings to be studied are selected on the basis of the dependent variable, that is, the researcher is unable to gain insight into whether or not the explanatory variable is associated with the dependent variable. Finally, the methods have a focus on identifying a single explanatory variable, whereas in social reality we most likely find that various variables interact in causing an event-known as multiple conjunctural causation (for an extensive critique to Mill's methods, see Lieberson, 1992).

These critiques are the starting point of an influential work in the development of the comparative method, Przeworski and Teune's Logic of Comparative Social Enquiry (1970). One of the research designs introduced by these authors is the most-similar-systems design. This design builds on the logic that the greater the similarity is between the settings being compared by relevant variables, the simpler it should be to trace an association between dependent and explanatory variables. This design helps the researcher to reduce the number of dependent and explanatory variables to be studied under controlled conditions - i.e. the cases are selected. The design is often considered to be an adaptation of Mill's method of difference, but it actually strongly differs from it (for an extensive discussion, see Levi-Faur, 2006). Whereas Mill's design selects cases based on dependent and explanatory variables Przeworski and Teune's design selects cases based on explanatory variables only-which may overcome the aforementioned selection bias related to Mill's method of difference.

The most-similar-systems design is the starting point of the illustrative study presented in the following section: a comparative analysis of the provision of building control and related services by state and non-state actors in Australia and Canada. These countries and the particular sector were selected for the high comparability in a number of relevant variables: both countries have a comparable governmental and judicial system (Dickerson \& Flanagan, 1998; Jackson \& Jackson, 2003); they have comparable building codes (ABCB, 2004; NRCC, 2005); they have similarly divided tasks and responsibilities with regard to building code enforcement amongst national, regional and local government and private sector agencies (Hansen, 1985; Lovegrove, 1991); and finally, they have an analogous approach to the privatization of public services (Özkaya \& Askari, 1999). The 
major difference between the hybrids studied is the different interaction between state and non-state service providers, as will be explained below.

\section{The cases studied}

The regulation of the safety, health, and amenity of people in buildings is deemed to be the responsibility of the provinces and territories in Canada (Hansen, 1985) and the states and territories in Australia (ABCB, 2002). In both countries the national government has nevertheless drawn up (comparable) advisory national building codes ( $A B C B, 2004$; NRCC, 2005). Currently all provinces, states and territories have implemented these national codes. Responsibility for enforcement of the building codes lies with the Canadian provincial and Australian state and territory governments. Traditionally, most of these governments have passed on many of their building regulatory powers to their municipal councils (Hansen, 1985; Lovegrove, 1991). These actors provide services such as the assessment of building plans against the building codes; the issuance of building permits when planassessment makes a reasonable case that there is compliance; the assessment of work under construction; and, the issuance of occupancy permits when construction workassessment makes a reasonable case that there is compliance.

Under a neo-liberal agenda, both in Canada and Australia non-state service providers were added to this institutional setting -in the 1980s in Canada, in the 1990s in Australia. The new hybrid settings of service delivery are highly comparable in both countries in that services are provided by both state and non-state service providers, and service recipients have a choice as to where to seek service. There is however a major difference between the two hybrid settings: in Australia a competitive interaction between the sectors was designed as part of the new hybrid (PC, 2004), but in Canada no specific interaction was designed and over time a complementary interaction has arisen (Van der Heijden, 2010b). Further, in Australia local councils are legally required to provide services, whereas in Canada local councils have a choice of whether to do so. Table 1 provides a brief summary of the designs of the new hybrid settings in Australia and Canada.

\section{$* * * *$ TABLE 1 ABOUT HERE $* * * *$}

To fully understand the cases presented, we need to pay closer attention to the specific sector studied. Broadly speaking, service recipients in the construction industry may be separated into two groups: practitioners, such as architects, engineers, contractors and developers, who are frequently and professionally involved in construction work; and, nonprofessionals, home-owners mostly, who are incidentally and personally involved in construction work. Galanter's typology of actors in legal systems clearly points to the distinctive characteristics of the two groups: the "repeat players" and the "one-shotters" (Galanter, 1974: 97). The following broad distinction may be made between the types of work provided by these groups: the repeat players are generally involved in major and often 
more complex construction works; the one-shotters are generally involved in minor and often less complex construction works.

\section{Data selection and analysis}

The illustrative study presented in this section has exploratory status. The research questions posed have a strong focus on the "hows" and "whys" of the impact of different interactions between public and private sector service providers. The main source of data collection was through semi-structured in-depth interviews (McCracken, 1988) with over a hundred representatives of local, provincial, and state governments; service providers such as public and private sector building code inspectors; and, service recipients such as architects, engineers, developers, contractors, and representatives of home-owner organizations. Interviewees were selected using "snowball" sampling (Longhurst, 2003), starting both in Australia and Canada with a key actor in the private and the public sector. This sampling resulted in a pool of potential interviewees from various backgrounds - ninety in Australia, seventy-six in Canada. In Australia interviews were carried out with fifty-six individuals in 2007 (62 percent); in Canada interviews were carried out with forty-seven individuals in 2008 (62 percent). All the questions posed had their origins in the following four main questions: Why was the hybrid setting introduced? How does the hybrid setting operate in daily practice? How is the hybrid setting evaluated? How are the goals that underpin the hybrid setting (not) achieved? By continuously moving between these four main questions it was possible to cross-check the consistency of the interviewees' answers during the interviews - it provided a structure for building in checks and balances within the in-depth interviews (Silverman, 2001). Appendix A provides a full overview of the interview questionnaire.

Collected data was coded from rough to fine by means of a systematic three-step coding scheme (Seale, Gobo, Gubrium, \& Silverman, 2004; Silverman, 2001). To triangulate findings from the data, secondary data such as existing studies, government reports, academic and grey literature on the topic and the specific cases were analyzed and included in the study. In addition, a follow-up questionnaire was sent to the interviewees after an initial analysis of the interview data. This questionnaire addressed twenty of the most frequently stated topics, for instance, "[private sector service delivery] and conflicts of interest go hand-in-hand due to commercial pressure." Interviewees were requested to react to these statements based on a four-point forced Likert scale. This follow-up questionnaire introduced the possibility for interviewees to react, to a certain extent, to each other's statements. It further provided the possibility of checking the consistency between interview statements and their agreement or disagreement with the questionnaire statements. Overall, these were consistent. Note that this statement questionnaire was returned by twenty-seven ( 48 percent) of the Australian interviewees and by sixteen ( 35 percent) Canadian interviewees. These relatively low response rates may be due to the fact that interviewees felt that they had already expressed their opinion and did not feel a need 
to do this again. As the data from the returned questionnaires were consistent with those of the interviews, the relatively low response rate is not considered problematic.

Computer aided software (the program ATLAS.ti) was used to run queries. By using this method it was possible to treat pieces of information in a comparable and systemized manner, thus gaining insight into "repetitive" and "deviant" experiences-where possible this is indicated in the case findings discussion in the following section. Finally, qualitative comparative analysis (Ragin, 2000; Ragin \& Strand, 2008) logic and tools were applied to trace patterns in the data. To further strengthen the internal validity of the inferences drawn from this study the research findings have been presented to the participants of the study and to a committee of academic supervisors, which has allowed them to reflect on the findings (Creswell \& Miller, 2000; Merriam, 1995). Furthermore, by continuously moving back and forward between data, research questions and theory, conclusions drawn are checked against existing research and internally within the illustrative study (cf. Brady \& Collier, 2004; Della Porta, 2008).

\section{Themes for comparison}

In gaining data on the illustrative comparative case study and in setting out the findings in the next section, the focus is on the perceived relative changes in the quality of the new hybrid settings of service delivery compared to the former pure state settings. Further, the perceived relative changes between the Australian and Canadian cases are compared. It is understood that "quality" is an ambiguous concept, so for the purposes of this study the term is unpacked in the following ways: (1) the quality of service delivery, (2) the quality of service providers, (3) the quality of services provided, and (4) the quality of the hybrid setting.

In what follows, the quality of service delivery relates to perceived changes in effectiveness and efficiency of service delivery in terms of processing times and costs (Hodge, 2000). The quality of service providers relates to perceived changes in the type of service providers and their level of education, skills and experience (Hodge, 2000). The quality of the services provided relates to perceived changes in meeting the service recipients' needs (Rothstein, 1998). Finally, the quality of the hybrid setting relates to the new settings as a whole, and the roles of the state and non-state service providers in particular (Noorderhaven, 1995). This last theme compiles the earlier three.

\section{Limitations of the illustrative case study}

Before discussing the illustrative study, some words of care need to be expressed. As discussed, the analysis presented should be understood as illustrative of the case made in this article, that is, of the need to address the interaction between service providers when studying hybrid settings of service delivery. The analysis presented is fully based on original interview data and secondary data obtained from existing literature. Both these datasets are inherently qualitative. 
When starting the illustrative study presented, it was expected that data would be available to compare, for instance, the (average) processing times and costs of building plan inspections prior to the introduction of the hybrid setting with those under the hybrid setting - a measure of the quality of service delivery. Ideally, data would have been available to further compare (average) processing times by state and non-state service providers - a measure of the quality of service providers. Unfortunately, such data could not be provided in either of the cases analyzed (for an extensive discussion of the data obtained, see Van der Heijden, 2010a; Van der Heijden, 2010b).The strengths of the qualitative datasets used, however, provide insight into the "how has X changed" themes addressed in Section 4.

\section{$4 \quad$ Findings from the illustrative case study}

This section presents the research findings structured by the earlier introduced themes of (i) the quality of service delivery, (ii) the quality of service providers, (iii) the quality of the services provided, and, (iv) the quality of the hybrid setting. Table 2 provides a summary of the main findings.

\section{$* * * *$ TABLE 2 ABOUT HERE ****}

\section{Quality of service delivery-Faster and cheaper?}

As discussed earlier, traditionally the literature on interacting service providers is concerned with competing non-state service providers. Competition then is assumed to be a driver for innovation and specialization. In order to survive and bring in clientele, service providers have to distinguish themselves from their competitors, and this, ultimately, will result in cheaper services for service recipients. This literature has a strong focus on the efficiency gains that competition brings (e.g. Becker \& Stigler, 1974; Harvey, 2005; Hodge, 2000; Landes \& Posner, 1975). If this reasoning holds true, one would expect to find greater increases in the quality of service delivery under the competitive form of interaction than under the complementary interaction in the cases studied.

Interviewees did indeed experience a more streamlined assessment and permit process in the hybrid settings compared to the former public settings, which, according to interviewees, resulted in time savings for applicants. Most Australian interviewees and a majority of the Canadian interviewees agreed that the inclusion of non-state service providers in the hybrid setting has resulted in efficiency gains compared to the former public settings (respectively 96 percent and 62 percent of the respondents to the follow-up questionnaire). However, the decrease in permit times was not associated with the different interactions between state and non-state service providers. In general, as both Australian and Canadian interviewees explained, non-state service providers have the ability to specialize, whereas state service providers have less ability do so-state service providers need to deal with all the work provided (cf. Wilson, 1989). Because of this specialization, non-state service providers often have in-depth experience of certain kinds of construction 
work, which may result in a speedier assessment process since the inspector knows "where to look and what to look for." Yet, a difference in incentives and administrative procedures was mentioned as well. Non-state service providers may be willing to speed up a process when this results in more income, or may pay their staff additional wages for working longer hours; whereas non-state service providers face a regime of fixed fees and pay their staff a fixed salary. Furthermore, non-state service providers may experience fewer time delays because of administrative procedures.

A reduction in prices was experienced at the top-end of the market, which is characterized by highly specialized construction work (e.g., complex structural work, innovative technological solutions, or the multifaceted use of land and construction). It is in this area that the non-state service providers find and compete for their clientele. A reduction in prices was not experienced at the lower end of the market. As a South Australian state official explained:

What you quite often find is that 20 per cent [of assessment work that is dealt with by] the Council will normally be composed of the small works: house extensions, alterations, and small structures - those sorts of things. ... The [nonstate service providers] don't want to know [the small works], because they're too messy and fiddly, and [they] would charge exorbitantly if you insisted them on doing [the small works] ... They really don't want the work." (Adelaide, 8 March 2007)

However, a South Australian none-state service provider made clear:

It is not that we don't like to do [the small works]. We're doing anything if there's a dollar in it. But the way fees are based on area ... If someone is doing a 50 square meter house addition and the [state service provider] therefore has to do it for a hundred dollars; we just can't do it for a hundred dollars. (Adelaide, 13 March 2007)

Interview accounts stress that competition does indeed result in a decline in the costs of services. However, it is not competition between state and non-state service providers, but the competition amongst non-state service providers that was considered to be the main driver for this decline in costs.

\section{Quality of service providers-Better trained and more experienced?}

Non-state service providers are sometimes found to be superior to state-service providers. Baldwin and Cave find that corporate bodies "can usually command higher levels of relevant expertise and technical knowledge than is possible with [public] regulation" (1999: 126). Furthermore, Ayres and Braithwaite find that "corporate inspectors are better trained and tend to achieve a greater inspectorial depth" than state inspectors (1992: 104). Non-state 
involvement is furthermore found to result in more "bang for the regulatory buck" (Gunningham, 2002: 5; Sparrow, 2000: 34). Due to a different approach to tasks or different organizational structures, the private sector appears, without additional capital, to carry out a more efficient enforcement process. Gunningham and Grabosky, for example, find that private-sector involvement "offers greater speed, flexibility, sensitivity to market circumstances, efficiency, and less government intervention than command and control regulation" (1998: 52).

Similar narratives were told by the interviewees in the Australian and Canadian cases. Non-state service providers were considered to be, on average, more experienced and better trained than their state counterparts. As a consequence non-state service providers are better suited to provide services in the profitable top-end of the market, where the highly specialized construction works naturally requires highly trained and very experienced staff. Furthermore, in both Australia and Canada certain legal requirements have been introduced specifying the level of education and experience needed to assess such complex construction work. For instance, in Australia only "full" building surveyors are allowed to assess complex construction works. A full building surveyor is required to hold at least a university degree (bachelor level) in a construction-related field and to have three years of working experience. In contrast, a "limited" building surveyor is only allowed to assess construction work of up to 2,000 square meters and three stories in height. A limited building surveyor is required to hold at least a diploma at a vocational education level in a construction-related field and to have six months of working experience. Comparable requirements apply in Canada.

By and large, state service providers are involved at the lower end of the market: family houses, house alterations, small construction works. Such works require a lesser level of education and experience than the works at the top-end of the market. Furthermore, state service providers appear to lose their well-trained and experienced staff to non-state service providers as the latter are able to provide better terms of employment including higher wages or fringe benefits such as a car, laptop, or cell-phone. "Municipalities have become the breeding grounds of cadets [trainees]," an Australian municipal official sighed. An Australian state official observed:

... where councils are probably understaffed or they don't have the skills, you tend to find the private guys certainly to be very qualified building surveyors, possibly having done some post-graduate studies. (Adelaide, 9 March 2007)

Another Australian state representative said:

The process got faster, but also [fees set by private certifiers] for larger projects went down, whereas the prices of the smaller domestic jobs went up. Small projects [and their clientele] are risky and difficult for the [non-state service provider] to deal with." (Brisbane, 11 April 2007) 
Again, interview accounts stress that competition may very well be a driver for service providers to increase their staff's level of education and experience. However, again interviewees only considered that the competition amongst non-state service providers was a relevant driver. The differences between state and non-state service providers were considered to be related to the specific industry-as we will see under the next quality criterion.

\section{Quality of services provided-Better meeting the demand for services?}

As we have seen in the second section of this paper, existing scholarship is concerned that non-state involvement in service delivery in general may result in a decline of social equity (Burkey \& Harris, 2006). This literature argues that all service recipients should be treated likewise in similar circumstances and that where all service recipients should have similar access to the service provided, non-state service providers are likely to prefer certain clientele over others, or to raise fees for profit. Due to this creaming, service recipients may face differences in treatment (Bailey, 1988; Stoker, 1998). Furthermore, not all service recipients may accept or be able to pay higher fees, and therefore they may be unable to obtain the service needed (Stone, 2002). Some state representatives who were interviewed raised similar concerns. The difference in the levels of education and experience found in state and non-state service providers was considered problematic, as this would result in a situation where not all service recipients could be provided with a similar level of service. Therefore the question is: Do the service recipients consider this to be problematic too?

Given the differences in involvement in construction work by repeat players and one-shotters (for terminology, see Section 3), the different groups have a different demands for services. Repeat players were considered to need expertise and timely services; oneshotters were considered to need guidance in the construction process. By and large, it was considered that repeat players would find that their demand was met by non-state service providers. As one of the non-state Australian service providers explained: "If they [repeat players] are doing a hospital, they can pick someone who has done a lot of hospitals; that compared with perhaps getting a novice from a council" (Adelaide, 13 March 2007).

That said, interviewees shared the opinion that one-shotters prefer to have their construction work assessed by state service providers. The interviewees mentioned the oneshotters' lack of trust in the private sector, when it comes to assessing their construction work against the public building codes. However, one-shotters appear to get more free help from state service providers. As one Canadian state official observed, "When [non-state] service providers don't get paid, they don't do it" (Calgary, 4 March 2008). This issue was clarified further by an official from a large Canadian municipality:

Our criticism of the private industry is that, because of time constraints, they sometimes say to the builder "correct and proceed." And on lesser issues, that is what our inspectors will do, but on more significant issues we'll say "correct and call 
us back." And as a result of that . . . trying to keep a fine balance between "correct this and call us back" versus "correct this and proceed," we probably, in many cases, do sixteen or seventeen inspections of a house. ... They might hit a house only once or twice and then it's finished. (Lethbridge, 6 March 2008)

In conclusion, both in Canada and Australia the new hybrid setting has resulted in a "natural fit" between service providers and service recipients: one-shotters generally seek service with state service providers, repeat players with non-state service providers. The different interactions between state and non-state service providers were not considered to result in a different demand-supply pattern in the cases studied.

\section{Quality of hybrid setting-Roles and interplay}

The above discussion does not provide indications that the differences in the types of interaction have an overall impact on the quality of service delivery, the quality of the service providers, or the quality of the service provided. As this section shows, the different interactions do have a number of consequences for the hybrid setting as a whole. Three issues stand out: the animosity between state and non-state service providers in Australia versus the cooperation in Canada; the slightly overweight state service providers in Australia versus the lean state service providers in Canada; and, the active attitude of the state service providers in Australia to the non-state service providers versus the passivity in Canada (Van der Heijden, 2011).

Considering animosity versus cooperation first, in the Australian case competition appears to have been introduced as a value rather than as an instrument (PC, 2004). Yet this competition is taken very literally by those working in the new hybrid setting. Interviewees from all the targeted groups referred to animosity between the state and non-state service providers. An Australian state representative said that, "The biggest pitfall in the system is the non-acceptance of private and council building surveyors of each other's work" (Melbourne, Australia, March 20, 2007). Under the current Australian regime, it appears the competitive relationship has resulted in two fully separated groups of service deliverers, who aim at achieving comparable goals: a safe, healthy, and durable built environment. The Canadian narrative was different. Here, the complementary relationship was perceived to result in cooperation between the groups. A Canadian state service deliverer sketched the scene as, "It's not competition: it's working side by side" (Vancouver, Canada, April 3, 2008). Canadian interviewees from both the state and non-state service providers stressed the importance of such cooperation as it made them aware of each other's strengths and knowledge.

Turning to the second issue, overweight versus lean state service providers, we have seen that clients involved in specialist or major works prefer non-state service providers over state service providers for their construction work. Yet this has resulted in a situation where state service providers lose large amounts of revenue-fees for assessment and permit issuance are a percentage of the total building costs. In order to overcome this loss 
of revenue and win back the profitable jobs, Australian state service providers hire specialists alongside their generalist staff. Their staff, however, are location-bound-they can only work within their jurisdiction - whereas non-state service providers can work all over Australia, like their clients with whom they often build long-term working relationships. Clients involved in major construction work, therefore, do not appear to move back to state service providers. In short, mismatches were reported between the state service providers' capacity to provide services and the services required. In Canada, state service providers have a choice as to what level of services to provide. In the case of the Greater Vancouver Regional District (population over two million), state service providers only provide a general level of service, suitable for most clients involved in nonspecific, noncomplex works. Clients involved in specialist or major construction works are advised to have their work assessed by non-state service providers. This has resulted in a situation where state service providers employ a specific kind of staff: generalists. Compared to their Australian counterparts, staff retained by Canadian state service providers are tailored to the level of service they provide and the specific group of clients they serve.

The third and final issue is the activism versus passivity of state service providers. In the previous sections we have seen that state service providers in Australia try to win back their turf. Hiring specialists is, however, not the only attempt by Australian state service providers to achieve this. Interviewees reported that there is a trend towards state service providers acquiring the characteristics of non-state service providers by providing more streamlined, client-friendly, and knowledgeable services (PC, 2004; VCEC, 2005). This confirms the findings by Price (2007) who likewise reports the up-skilling of state agencies in response to competition from non-state counterparts.

The Canadian narrative was, again, different. Instead of aiming to skill their services up to the level of non-state service providers, the complementary relationship provided the Canadian state service providers with the possibility of taking a different path; that is, they specialized in the work of one-shotters. This "specialization" may, however, be termed "down-skilling" because the state service providers are unable to assess the more complex and major works, which they leave to non-state service providers. Although this was earlier discussed as a positive transition from an overweight to a lean state service provider, the downside is that government in general becomes dependent on non-state service providers to carry out certain public tasks. This, as the Canadian interviewees highlighted, limits the possibilities of steering these non-state service providers' behavior-of which the most extreme measure is to take them out of the market. This was truer for certain Canadian regions, as only a limited number of non-state service providers provided services. Taking one of these service providers out of the market would imply that construction policyrelated services will no longer be carried out there. A provincial official therefore wondered, "What would we do if [non-state service providers] close their doors?" (Calgary, Canada, March 5, 2008). 


\section{$5 \quad$ Discussion and conclusion}

This article has highlighted a gap in our understanding of hybrid settings of public service delivery. Whereas existing literature on such settings traditionally compares the former non-hybrid public settings with the new hybrid settings, this article has addressed the interaction between state and non-state service providers in a hybrid setting. To illuminate the relevance of including this understudied aspect of hybrid settings in our studies an illustrative case study was presented. The illustrative case study addressed the different positions in two slightly different hybrid settings: one characterized by a competitive interaction between state and non-state service providers (Australia), the other by a complementary interaction (Canada).

Broadly speaking the illustrative case study has shown that, as a result of the introduction of non-state service providers, improvements were reported in of quality of service delivery, quality of services delivered, and quality of service providers. These improvements generally confirm existing theorizing on these topics. The study furthermore indicates that the type of interaction between state and non-state service providers does not appear to affect these improvements. However, the major finding from this study is that the particular type of interaction does affect the hybrid setting as a whole. In the two cases discussed we have seen differences in the willingness of state and non-state service providers to collaborate; the risk of state service providers becoming overweight when they aim to mirror the characteristics of non-state service providers; and conversely, the threat of state service providers becoming too dependent on non-state service providers when down-skilling their own staff. To conclude, the competitive interaction appears to be most suitable if only efficiency gains are sought; yet, when the hybrid setting is intended to serve a redistributive function as well, a complementary interaction appears more suitable.

These are just some of the various impacts different interactions between state and non-state service providers may have. Additional empirical research in different countries and different policy areas is needed to gain a better understanding of the possible range of potential interactions between these groups of service providers, and their impact on the hybrid settings implemented. Additionally, quantitative research may also be of value to gain a better understanding of how much and how often different interactions impact on hybrid settings. This article simply aims to make scholars aware of the importance of these interactions in hybrid settings for service delivery. 


\section{Tables}

Table 1 - the designs of the new hybrid settings compared

\begin{tabular}{|l|l|l|}
\hline Hybrid element & Canada & Australia \\
\hline $\begin{array}{l}\text { Responsibilities for setting } \\
\text { Building Codes }\end{array}$ & Federal Government & Federal Government \\
\hline $\begin{array}{l}\text { Responsibilities for } \\
\text { implementing Building Codes }\end{array}$ & $\begin{array}{l}\text { Regional Government } \\
\text { (Provinces) }\end{array}$ & $\begin{array}{l}\text { Regional Government } \\
\text { (States \& Territories) }\end{array}$ \\
\hline Day-to-day service delivery & $\begin{array}{l}\text { Local councils and non-state } \\
\text { service providers }\end{array}$ & $\begin{array}{l}\text { Local councils and non-state } \\
\text { service providers }\end{array}$ \\
\hline Choice for service recipients & Yes & Yes \\
\hline $\begin{array}{l}\text { Interaction between service } \\
\text { providers }\end{array}$ & Complementary & Competition \\
\hline $\begin{array}{l}\text { Choice for local councils to } \\
\text { provide services }\end{array}$ & Yes & $\begin{array}{l}\text { No-service provision is } \\
\text { required }\end{array}$ \\
\hline $\begin{array}{l}\text { Interaction as conscious choice } \\
\text { in hybrid design }\end{array}$ & No-it originated over time & Yes \\
\hline
\end{tabular}


Table 2 - Overview of the main findings.

\begin{tabular}{|c|c|c|}
\hline & Canada & Australia \\
\hline Quality of service delivery & $\begin{array}{l}\text { - } \quad \text { Efficiency gains due to } \\
\text { non-state service } \\
\text { providers' ability to } \\
\text { specialize. }\end{array}$ & $\begin{array}{l}\text { - Efficiency gains due to } \\
\text { private sector service } \\
\text { providers' ability to } \\
\text { specialize. } \\
\text { - } \quad \text { Creaming attitude of } \\
\text { private sector service } \\
\text { providers. }\end{array}$ \\
\hline Quality of service providers & 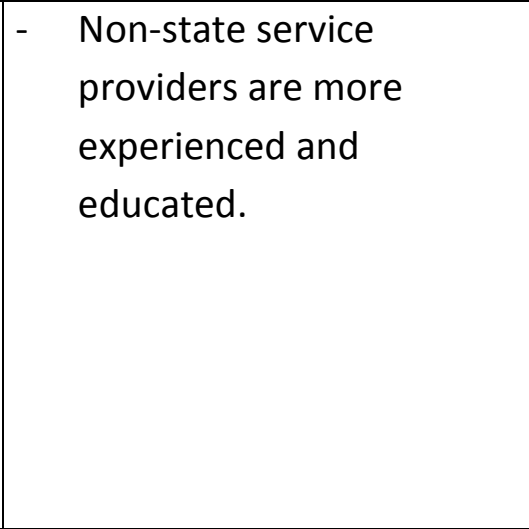 & 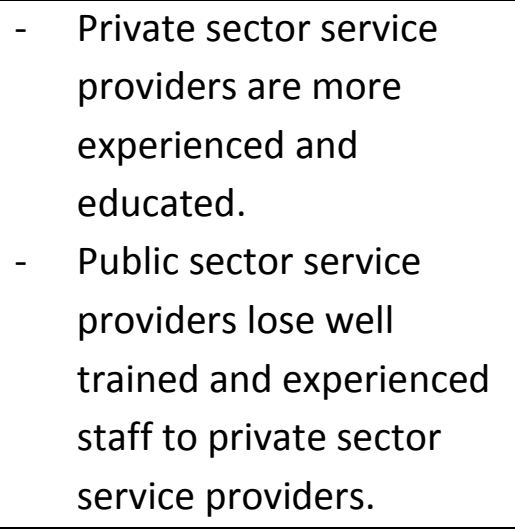 \\
\hline Quality of service provided & $\begin{array}{l}\text { - A natural fit between } \\
\text { service providers and } \\
\text { service recipients. }\end{array}$ & $\begin{array}{l}\text { - A natural fit between } \\
\text { service providers and } \\
\text { service recipients. }\end{array}$ \\
\hline Quality of hybrid setting & 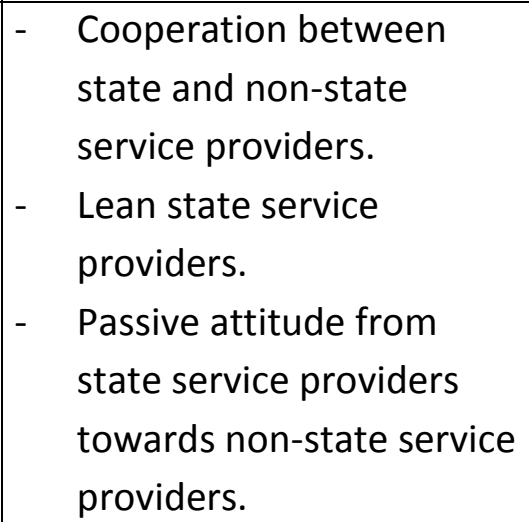 & $\begin{array}{ll}\text { - } & \text { Animosity between } \\
\text { public and private service } \\
\text { providers. } \\
\text { - } \quad \text { Slightly overweight state } \\
\text { service providers } \\
\text { - } & \text { Active attitude from } \\
\text { state service providers } \\
\text { towards non-state } \\
\text { service providers. }\end{array}$ \\
\hline
\end{tabular}




\section{Appendix A - Overview of the main interview questions (topic and question numbers)}

\section{Introduction}

1a What do you think about the quality of the building industry in [jurisdiction]?

1b To what extent is a certain development perceivable in the building industry?

Why was the new regime introduced?

2. Preceding this interview I sent you a short overview, my perception, of the [old and new regime] in [jurisdiction]. To what extent is this an accurate description?

3a Why was the [new regime] introduced?

How does the regime operate in daily practice?

5a To what extent can [local government] interfere in the [private sector] assessment process?

5b And to what extent does [local government]?

6 To what extent has compliance (with building regulations) changed after the introduction of [the new regime]?

7a To what extent can acceptable evidence be found of the achievement of regulatory objectives?

7b Could you state websites, research reports or articles that might be of help to my further research?

9a To what extent is building control performed equally amongst different groups?

9b To what extent is building control performed equitably by the different sectors (public and private sector enforcement actors)?

How is the regime evaluated?

3b Do applicants show a preference for either [public or private sector involvement]?

3c If so, why?

4a What are the criteria to be allowed to enforce building regulations (for both public and private sector actors)?

4b. Are these criteria realistic (qualitatively and quantitatively)?

10a What are the statutory responsibility and liability of different enforcement parties (public and private sector actors)?

10b Are these realistic?

11a How are the different enforcement actors (public and private) overseen by [different levels of government]?

$11 \mathrm{~b}$ To what extent is this oversight realistic?

Why are goals that underpin the regime (not) achieved?

$1 \mathrm{c} \quad$ Why is building control needed in [jurisdiction]? 
8a What is the most serious obstacle to achieving objectives of the building regulations? Why?

$8 \mathrm{~b} \quad$ What is the second most serious obstacle to achieving objectives? Why?

$8 \mathrm{c}$ [If the interviewee mentions more objectives, try to have these ordered.]

12 If you were allowed to change one thing in the new regime, what would it be? And why?

\section{Final question}

13 Is there anything you think I have missed in this interview, or is there anything you wish to add? 


\section{References}

ABCB. (2002). The Performance Building Code of Australia. Canberra: Australian Building Codes Board

ABCB. (2004). BCA 2004. Canberra: Australian Building Codes Board.

Ayres, I., \& Braithwaite, J. (1992). Responsive Regulation. Transcending the Deregulation Debate. New York: Oxford University Press.

Baggesen Klitgaard, M. (2008). School Vouchers and the New Politics of the Welfare State. Governance, 21(4), 479-498.

Bailey, T. R. (1988). Market Forces and Private Sector Processes in Government Policy. Journal of Policy Analysis and Management, 7(2), 300-315.

Baldwin, R., \& Cave, M. (1999). Understanding Regulation. New York: Oxford University Press.

Barnard, C. I. (1938). The functions of the executive (1968, 30th anniversary edition ed.). Cambridge: Harvard University Press.

Becker, G. S., \& Stigler, G. J. (1974). Law Enforcement, Malfeasance, and Compensation of Enforcers. Journal of Legal Studies, 3(1), 1-18.

Brady, H. E., \& Collier, D. (Eds.). (2004). Rethinking Social Inquiry. Lanham: Rowman \& Littlefield Publishers.

Burkey, J., \& Harris, T. R. (2006). Impacts of privatization. The Social science journal., 43(4), 617-628.

Cellini, R., Pignataro, G., \& Rizzo, I. (2000). Competition and Efficiency in Health Care. International Tax and Public Finance, 7(4/5), 503-519.

Creswell, J. W., \& Miller, D. L. (2000). Determining Validity in Qualitative Inquiry. Theory Into Practice, 39(3), 124-130.

Daniels, N. (1990). Equality of what: welfare, resources, or capabilities? Philosophy and Phenomenological Research, 1(Fall), 73-98.

Davidson, A. (1999). Alternative Mode Is of Social Housing. Housing Studies, 14(4), 453-472.

Della Porta, D. (2008). Comparative analysis: case-oriented versus variable oriented research. In D. Della Porta \& M. Keating (Eds.), Approaches and Methodologies in the Social Sciences (pp. 198-222). Cambridge: Cambridge University Press.

Dickerson, M. O., \& Flanagan, T. (1998). An Introduction to Government and Politics. Scarborough: International Thomson Publishing.

Dowding, K. (2006). Can Capabilities Reconcile Freedom and Equality? Journal of Political Philosophy, 14(3), 323-336.

Fotaki, M., (2011). Towards Developing New Partnerships In Public Services. Public Administration, 89(3), 933-955

Fotaki, M., Boyd, A., Smith, L., McDonald, R., Ronald, M., Sheaff, R., Elwyn, G. (2005). Patient Choice and the Organisation and Delivery of Health Services. Manchester: University of Manchester. 
Fotaki, M., Roland, M., Boyd, A., McDonald, R., Scheaff, R., \& Smith, L. (2008). What benefits will choice bring to patients? Journal of Health Services Research \& Policy, 13(3), 187184.

Galanter, M. (1974). Why the "haves" come out ahead. Law and Society Review, 9(Fall), 95160.

Giddens, A. (2000). The Third Way and its Critics. Cambridge: Polity Press.

Greener, I., \& Powell, M. (2008). The Evolution of Choice Policies in UK Housing, Education and Health Policy. Journal of Social Policy, 38(1), 63-81.

Gunningham, N. (2002). Regulating Small and Medium Sized Enterprises. Journal of Environmental Law, 14(1), 3-32.

Gunningham, N., \& Grabosky, P. (1998). Smart Regulation. Oxford: Oxford University Press. Habermas, J. (1976). Legitimation Crisis. Cambridge: Polity Press.

Ham, C., \& Brommels, M. (1994). Health Care Reforms in the Netherlands, Sweden and the United Kingdom. Health Affairs, 13(5), 106-119.

Hansen, A. T. (1985). The regulation of building construction. Ottawa: National Research Council Canada.

Harvey, D. (2005). A brief history of neoliberalism. Oxford: Oxford University Press.

Hodge, G. A. (2000). Privatization: An International Review of Performance. Boulder: Westview Press.

Jackson, R. J., \& Jackson, D. (2003). An Introduction to Political Science: comparative and world politics. Toronto: Prentice Hall.

Jordan, A., Wurzel, R., \& Zito, A. (2005). The Rise of New Policy Instruments in Comparative Perspective. Political Studies, 53(3), 477-496.

Korpi, W., \& Palme, J. (1988). The Paradox of Redistribution and Strategies of Equality. American Sociological Review, 63(5), 661-687.

Landes, W. M., \& Posner, R. A. (1975). The Private Enforcement of Law. The Journal of Legal Studies, 4(1), 1-46.

Le Grand, J. (2007). The Politics of Choice and Competition in Public Services. The Political Quarterly, 78(2), 207-213.

Levi-Faur, D. (2006). A Question of Size? In B. Rihoux \& H. Grimm (Eds.), Innovative Comparative Methods for Policy Analysis (Vol. 43-66). New York: Springer/Kluwer.

Lieberson, S. (1992). Small N's and big conclusions. In C. C. Ragin \& G. S. Becker (Eds.), What is a Case? (pp. 105-118). Cambridge: Cambridge University Press.

Longhurst, R. (2003). Semi-structured Interviews and Focus Groups. In N. J. Clifford \& G. Valentine (Eds.), Key methods in geography (pp. 117-132). London: Sage Publishers.

Lovegrove, K. (1991). The Primary Building Acts of Australia. Sydney: The Federation Press.

McCracken, G. (1988). The long interview (Vol. 13). London: Sage.

Merriam, S. B. (1995). What Can You Tell From An N of 1? PAACE Journal of Lifelong Learning, 4, 51-60.

Mill, J. S. (1851 [1843]). A System of Logic (3rd edition ed.). London: Longmans, Green, and co. 
Minow, M. (2011). Confronting the seduction of choice. Yale Law J. Yale Law Journal, 120(4), 814-848.

Noorderhaven, N. G. (1995). Transaction, Interaction, Institutionalization. Scandinavian Journal of Management, 11(1), 43-55.

NRCC. (2005). National building code of Canada, 2005. Ottawa: National Research Council Canada.

Osborne, D., \& Gaebler, T. (1992). Reinventing government. Reading: Addison-Wesley Publishers.

Özkaya, M., \& Askari, H. (1999). Management of Newly Privatized Companies. World Development, 27(6), 1097-1114.

Parkin, M., Powell, M., \& Matthews, K. (2005). Economics. Boston: Addison-Wesley.

PC. (2004). Reform of building regulation. Melbourne: Productivity Commission, Commonwealth of Australia.

Petersen, J. H. (2010). Marketization and free choice in the provision of social services. In P. Kettunen \& K. Petersen (Eds.), Beyond Welfare State Models (pp. 170-198). Cheltenham: Edward Elgar.

Pierson, C., \& Casteles, F. (Eds.). (2006). The Welfare State Reader. Second Edition. Cambridge: Polity Press.

Price, B. E. (2007). The Treat of Privatization. International Journal of Public Administration, 30(11), 1141-1155.

Przeworski, A., \& Teune, H. (1970). The logic of comparative social inquiry. New York: WileyInterscience.

Pugh, D. (Ed.). (2007). Organization Theory. Fifth edition. Londong: Penguin Books.

Ragin, C. C. (2000). Fuzzy-Set Social Science. Chicago: University of Chicago Press.

Ragin, C. C., \& Strand, S. I. (2008). Using Qualitative Comparative Analysis to Study Causal Order. Sociological Methods and Research, 36(4), 431-441.

Rothstein, B. (1998). Just Institutions Matter. New York: Cambridge University Press.

Seale, C., Gobo, G., Gubrium, J. F., \& Silverman, D. (2004). Qualitative Research Practice. London: Sage.

Silverman, D. (2001). Interpreting Qualitative Data. 2nd edition. London: Sage.

Sparrow, M. K. (2000). The Regulatory Craft. Washington: Brookings Institution.

Stoker, G. (1998). Governance as theory: five propositions. International Social Science Journal, 50(155), 17-28.

Stone, D. A. (2002). Policy Paradox. New York: Norton.

Trubek, D., \& Trubek, L. G. (2007). New Governance \& Legal Regulation. Columbia Journal of European Law, 13(3), 539-564.

Van der Heijden, J. (2010a). On Peanuts and Monkeys: Private Sector Involvement in Australian Building Control. Urban Policy and Research, 28(2), 195-2101.

Van der Heijden, J. (2010b). One task, a few approaches, many impacts: private sector involvement in Canadian building control. Canadian Public Administration, 53(3), 351-374. 
Van der Heijden, J. (2011). Friends, enemies or strangers? On relationships between public and private sector service providers in hybrid forms of governance. Law \& Policy, 33(3), 367-390.

Van Slyke, D. M. (2003). The Mythology of Privatization in Contracting for Social Services. Public Administration Review, 63(3), 296-315.

VCEC. (2005). Housing Regulation in Victoria, Final Report. Melbourne: Victorian Competition and Efficiency Commission.

Williamson, O. E. (1996). The mechanisms of governance. New York: Oxford University Press. Wilson, J. Q. (1989). Bureaucracy. New York: Basic Books.

Young, D. R. (2006). Complementary, Supplementary, or Adversial? In E. T. Boris \& C. E. Steurele (Eds.), Nonprofits and Government (pp. 37-80). Washington, D.C.: Urban Institute Press. 